\title{
수지골절-탈구치료의최신지견
}

\author{
강호정・김지섭*쪼
}

연세대학교 의과대학 강남세브란스병원 정형외과학교실, *이화여자대학교 의과대학 이대서울병원 정형외과학교실

\section{The Current Concepts in Treatment of Fracture-Dislocations of the Finger}

\author{
Ho Jung Kang, M.D., Ph.D. and Ji Sup Kim, M.D.* \\ Department of Orthopedic Surgery, Gangnam Severance Hospital, Yonsei University College of Medicine, ${ }^{*}$ Department of Orthopaedic Surgery, \\ Ewha Womans University Seoul Hospital, Ewha Womans University College of Medicine, Seoul, Korea
}

Fingers are body parts with a complex structure and essential functions that are the most prone to trauma. The principle of treatment for finger fractures is to determine the balance between obtaining stable fracture fixation and early joint movement. Despite proper treatment, there are many cases of functional and cosmetic problems caused by stiffness or deformation as complications. This review article introduces the latest knowledge in the treatment of finger fractures focusing on fractures and dislocations around the interphalangeal joints, including joint surface damage, which is difficult to treat and leads to poor results. This article consists of fracture cases and describes the methods and solutions to address these complications.

Key words: finger, fracture, dislocation, fixation, complications

\section{서 론}

서론에서는 수지 골절 및 탈구의 일반적인 치료 원칙을 설명하 고 최근 소개되어 각광받고 있는 수부 각성 수술(wide-awake hand surgery)을 통한 골절 치료에 대해서 간략히 소개한다.

\section{1. 수지 골절 및 탈구의 일반적인 치료 원칙}

골절이 의심되면 방사선 촬영을 시행한다. 일반적으로 전후면, 측면, 사면 촬영을 시행하며, 수지 손상의 경우에는 이환된 수지 의 단독 전후면 및 측면 촬영이 반드시 필요하다. 방사선 촬영만 으로는 관절내 골절의 상태를 확인하기 어려워 컴퓨터 단층 촬영 (computed tomography)이 필요한 경우가 많다. 환자 내원 시

Received June 23, 2020 Revised September 1, 2020

Accepted September 7, 2020

Correspondence to: Ji Sup Kim, M.D.

Department of Orthopaedic Surgery, Ewha Womans University Seoul Hospital, 260 Gonghang-daero, Gangseo-gu, Seoul 07804, Korea

TEL: +82-2-6986-1774 FAX: +82-2-2642-0349 E-mail: kkimjsno1@naver.com

ORCID: https://orcid.org/0000-0001-8448-1064
방사선에서 보이는 골절 이외에도 간과되기 쉬운 건, 인대, 신경 및 혈관의 손상 여부를 세심하게 살펴야 한다. 골절의 정복 후 안 정성이 유지되는 경우는 부목 고정이나 주변 수지를 같이 고정하 는 동반 테이핑(buddy taping)과 같은 비 수술적 방법을 시도한 다. 규칙적인 추시 관찰을 통해서 각형성이나 회전 변형 등의 부 정 유합이나 감염 등의 합병증을 예방하여야 한다. 특히, 회전 변 형은 단순 방사선 영상 검사만으로는 정확한 판단이 어려워서 통 증이 있고 부종이나 통증이 있더라도 직접적인 시진 및 수지 운 동을 능동적으로 부분적 제한 범위 내에서 운동을 시켜보면서 임 상적으로 판단해야 한다. 회전 변형의 판정 방법은 정상 수지에 서 무지를 제외한 네 수지는 파악(full grip) 자세 시 서로 평행하 며, 각 수지의 말단부가 주상골의 조면(tuberosity)을 향한다. 또 한 주먹을 쥘 때 수지가 서로 겹치지 않는지 확인하고 강직이나 통증으로 구부릴 수 없는 경우는 손톱면의 배열을 통해 회전 변 형 여부를 확인할 수 있다(Fig. 1). 환자가 마취된 상태에서는 건 고정 효과(tenodesis effect)를 이용한 손목의 수동 신전으로 손 가락을 굴곡시켜 회전 변형 여부를 확인할 수 있다.

보존적 치료 방법으로 골절의 안정성이 확보되지 않을 경우에 

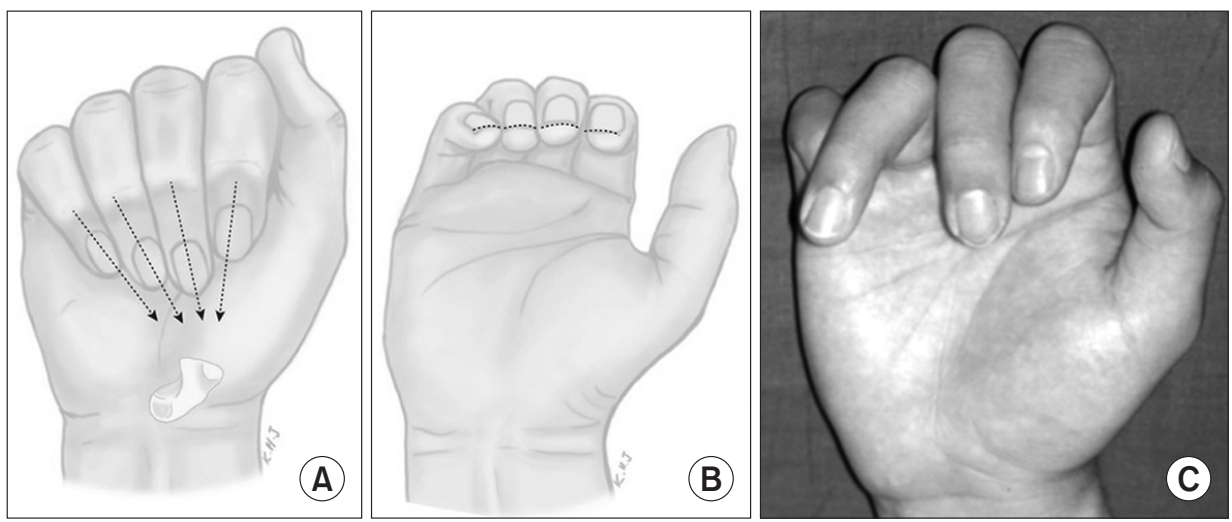

Figure 1. Rotational deformity is assessed by (A) checking for alignment of the fingertips to the scaphoid tuberosity; (B) evaluating the plane of the fingernails. $(\mathrm{C})$ Rotational deformity of the ring finger by proximal phalanx malunion.
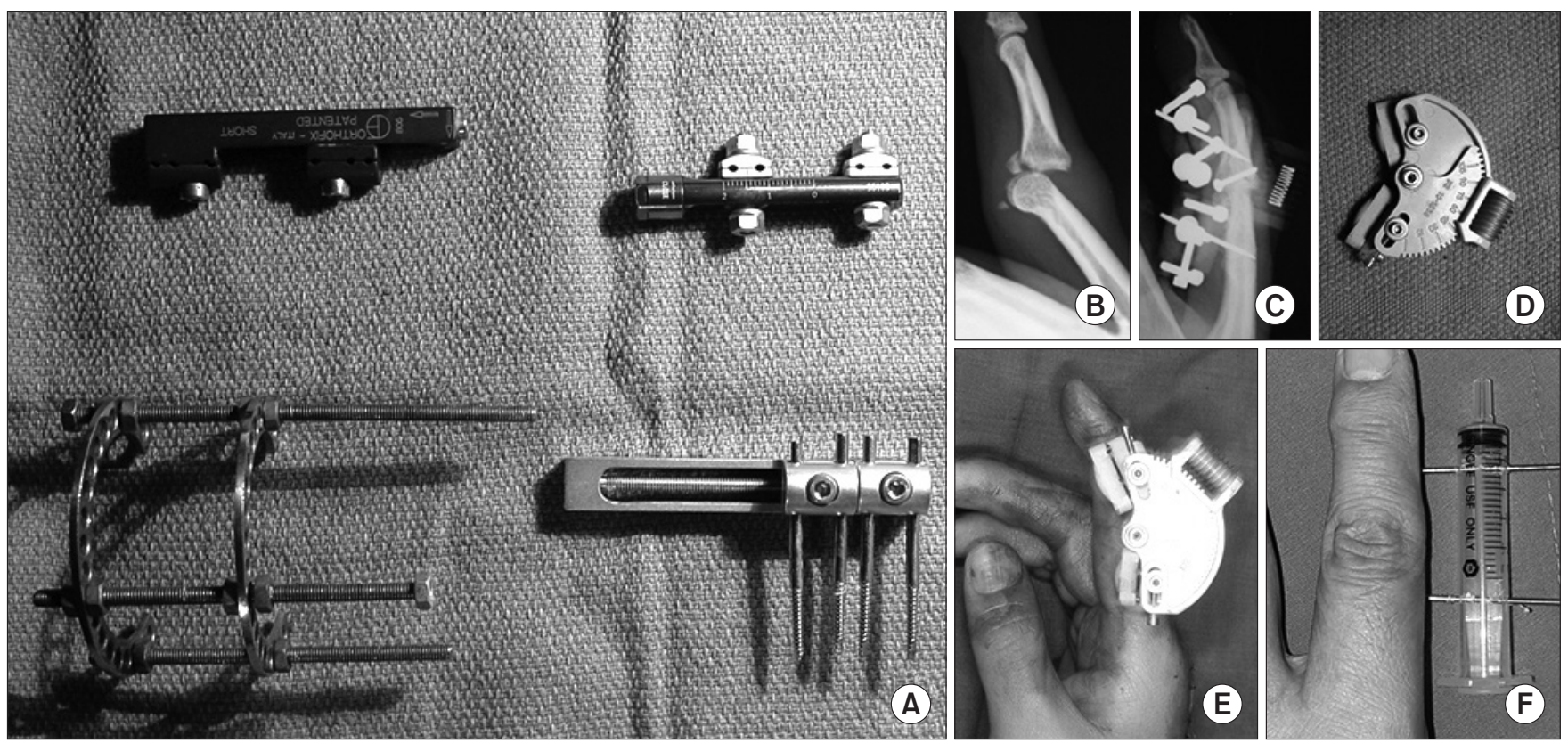

Figure 2. Various External fixation devices used to treat finger joint fracture-dislocations. (A) Various external fixation devices for finger joint fracturedislocations. (B-E) The hinged dynamic external fixator for the treatment of fracture dislocations of the proximal interphalangeal joint. $(F)$ The syringe external fixator can be used when it is difficult to use an external fixator in the operation room.

는 수술적 치료를 고려한다. 수지골절의 치료 목적은 파악 동작 을 회복하고 강직이나 변형 등의 합병증을 피하는 것이다. 술 후 강직을 예방하기 위해서는 해부학적 정복과 견고한 고정을 통한 조기 관절 운동이 요구된다. 최근 내고정물의 소형화와 재질의 발달에 의하여 작은 골절편에서도 고정 시 안정성을 제공하여 조 기 관절 운동이 가능한 다양한 내고정물들이 사용되고 있다. 흡 수성 핀이나 소형 고정나사, 소형 갈고리 금속판, 소형 잠김 금속 판 등의 다양한 내고정물을 이용하여 좋은 결과를 기대할 수 있 다. 그럼에도 불구하고 수지골절에서 도수정복이나 관혈적 정복 후 고정 시 널리 쓰이는 $\mathrm{K}$-강선은 쉽게 사용이 가능하고, 경피 적 고정으로 연부조직 손상을 최소화하면서 안정된 고정을 유지 하며, 제거가 간편한 좋은 내고정물임을 잊지 말아야 한다. ${ }^{1)}$ 심
한 수지 관절 주위의 과간 골절이나 관절면의 감입 및 탈구가 동 반된 골절, 수지골 경부의 분쇄 골절, 양측 측부인대 견열골편을 동반한 심한 분쇄 골절에서는 소형화된 수지 외고정 장치의 사 용이 필요하고, 외고정 기구의 응급 사용이 어려운 경우에는 K강선 등을 이용한 견인 및 능동적 운동 외고정 치료나 손상부 주 위 수지관절의 해부학적인 위치에서의 임시적 경관절 핀 고정 (trans-articular joint fixation)을 3-4주간 단기적으로 시행할 수 있다(Fig. 2).

\section{2. 각성 수술법을 이용한 수지 골절 치료}

최근 국소 마취를 위한 리도카인(lidocaine)과 지혈대가 없이 혈 관 수축 효과를 지닌 에피네프린(epinephrine)을 이용한 수부 
The Current Concepts in Treatment of Fracture-Dislocations of the Finger

각성 수술(wide awake local anesthesia no tourniquet) 기법 이 소개된 이후 수지 및 수부의 대부분의 수술에서 널리 이용되 고 있다. ${ }^{2.3)}$ 골절에서 각성 수술 마취 용법은 다음과 같다. $1 \%$ 리 도카인과 $1: 100,000$ 에피네프린을 $10 \mathrm{ml}$ 주사기에 채우고, 리도 카인 $10 \mathrm{ml}$ 당 $8.4 \%$ 바이카보네이트 $1 \mathrm{ml}$ 를 섞어 10:1의 비율로 중화한다. 수술 부위에 따라서 10-20 ml를 수술이 이루어지는 모든 부위 피하에 천천히 주사한다. 골절 부위 근위부의 골막 주 위 마취를 통하여 환자의 불편감을 경감시킬 수 있다.

수부 각성 수술의 장점은 술자와 환자가 능동적인 관절의 움직 임을 통해서 예상되는 술 후 결과를 술장에서 직접 확인이 가능 하다는 점이다. ${ }^{4}$ 수지 및 수부 골절 시 수술이 필요한 모든 불안 정성 골절에서 각성 수술 접근이 가능하며, 능동적인 관절 운동 을 통해 골절 고정 후 안정성을 수술장에서 평가할 수 있다. 이러 한 능동적 관절 운동을 통한 수술 중 안정성 평가는 수술 후 환자 의 빠른 회복을 돕고, 술 후 강직 발생을 최소화할 수 있다. ${ }^{3)}$ 또한 외상 이후 발생한 신전 구축(extension contracture)이나 굴곡 구축, 부분적 관절운동 장해 시에도 각성수술을 이용한 건유리술 이나 관절 해리술 등으로 치료 결과의 향상을 도모할 수 있다.

본문의 기술 순서는 수지 각 관절에서 발생하는 관절 내 골절 및 탈구에 대해서 원위지간, 근위지간, 중수지관절 순서로 치료 방법을 정리하였으며, 무지의 중수지관절 손상과 중수골 기저부 골절은 타 수지에 비해 높은 발생 빈도와 무지 기능의 중요성을 고려하여 추가하여 소개하고 마지막으로 골절 치료 후 발생한 합 병증 치료에 대해서 요약하였다.

\section{본 론}

\section{1. 원위지간 관절 손상}

원위지골은 수부에서 골절이 가장 흔하게 발생하는 부위이나 대 부분의 경우 보존적 치료로 해결된다. 흔히 발생하는 관절내 골 절인 골성 추지(bony mallet finger)와 드물게 발생하지만 수술 적 치료가 필요한 심수지굴건 견열 골절(avulsion fracture)의 치 료에 대해서 기술하였다.

\section{1) 골성 추지}

골성 추지의 기본적인 치료는 건성 추지와 동일하게 적어도 6주 이상 신전부목을 통한 장기간 고정이다. 고정 기간은 환자의 상 태와 잔존 변형의 정도에 따라서 8주까지도 가능하다. 초기에 환 자가 변형이나 통증이 심하지 않아서 1-2개월의 간과된 추지 기 형에서도 수술적 치료가 아닌 보존적 치료로 좋은 결과를 얻을 수도 있다. 원위지간관절의 장기간 완전한 고정이 치료에 필수 적이므로 환자가 치료에 순응할 수 있도록 세심한 설명과 교육 이 필요하며 정기적인 외래 관찰을 하면서 살펴야 한다. 아직까 지 수술의 적응증에 대해서는 이견이 있지만 개방성 손상인 경우 에 장기간의 부목고정의 유지가 불가능하거나 보존적 치료에 비 순응적인 환자에서 수술을 시행할 수 있으며, 관절면의 $1 / 3$ 이상 포함하는 큰 골편이 있는 골절이면서 원위지골의 수장측 아탈구 가 동반된 경우 수술을 시행할 수 있다. 수술적 치료 방법으로 비 관혈적 방법인 신전제한 핀고정술, 관혈적 방법으로 나사 고정술, pull-out 강선 고정술, 소형 금속판 고정술 등이 있다(Fig. 3)."

합병증으로는 부목 고정과 관련되어 피부궤양 등이 발생할 수 있다. 연부조직이 타 관절에 비해서 얇고, 손톱 배아기질(germi-
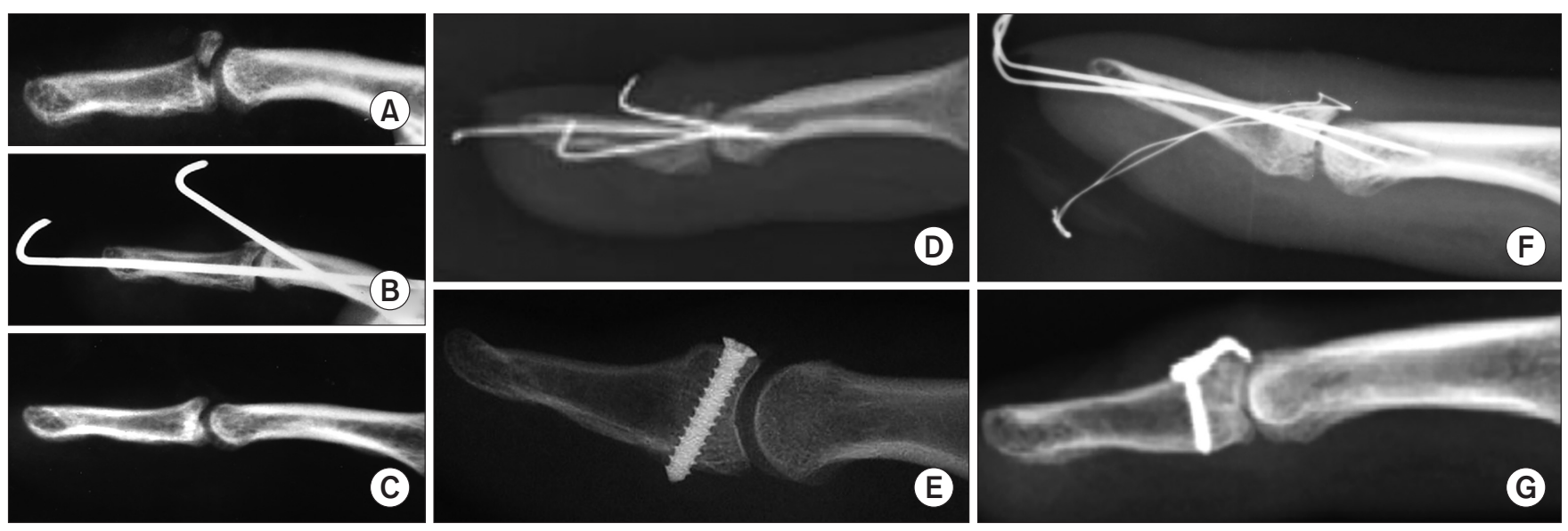

Figure 3. Various fixation methods for mallet fracture. Closed extension block K-wire fixation technique. (A) Preoperative X-ray of bony mallet finger with 1/2 articular involvement, without volar subluxation of the distal interphalangeal (DIP) joint. (B) Closed reduction and percutaneous pinning of the fracture. (C) Follow-up X-ray at 12 months shows full bone union and joint congruity. (D) Open reduction and K-wires fixation \& additional DIP joint fixation technique. (E) Open reduction and screw fixation technique. (F) Open reduction and pull-out wire and DIP joint K-wire fixation technique. (G) Open reduction and hook plate fixation technique. 
nal matrix)이 손상되기 쉽기 때문에 관혈적 수술 치료 후 수술 부위 괴사(24\%), 굴곡변형의 재발(13\%), 감염(7\%), 손톱변형(7\%) 등의 합병증이 발생할 수 있으며, 이는 비 관혈적 치료 시 발생하 는 합병증보다 더 많으므로 치료 시 주의를 요한다(Fig. 4). ${ }^{\text {) }}$

\section{2) 심수지굴건 견열 골절}

럭비 운동 시에 손가락 끝부분이 운동복의 깃(collar) 부분에 걸 려 당겨지면서 손상이 발생을 하여 'Jersey (운동 경기용 셔츠)' 수지라고도 한다. 심수지굴건이 원위지골 기저부에 넓게 분포 종 지(insertion)하기 때문에 손상 시 파열보다는 견열 골절의 형태 로 나타나는 경우가 많다. 진찰 시 원위지 관절의 능동적 굴곡이
불가능하다면 심수지건의 견열 골절을 의심해봐야 한다. 1977년 Leddy와 Packer ${ }^{7}$ 가 3 개의 형태로 분류하였고, 원위지골의 골절 형태 건열 골편의 위치, 건의 퇴축 위치 등에 따라서 $\mathrm{Smith}^{8)}$ 가 제 4형을, $\mathrm{Al}-\mathrm{Qattan}{ }^{9}$ 이 제 5형을 추가하였으며, 5가지 형태 모두 기본적으로 수술을 요한다. 이 중 제 5형은 견열 골절이 있으면서 동시에 원위지골의 간부골절이 동반되는 경우로, 제 $5 \mathrm{a}$ 의 경우 관 절 외 동반 골절, $5 \mathrm{~b}$ 의 경우 관절내 동반 골절이 있는 경우, $5 \mathrm{c}$ 는 심수지 굴건의 견열이 동시에 일어나 제 1,4 형과 같이 건이 손바 닥으로 응축되어 빠른 치료가 요한다(Fig. 5).

골편이 작거나 골편에서 떨어진 건의 경우 pull-out 방법으 로 봉합(pull-out suture repair)하거나 소형 고정나사(suture
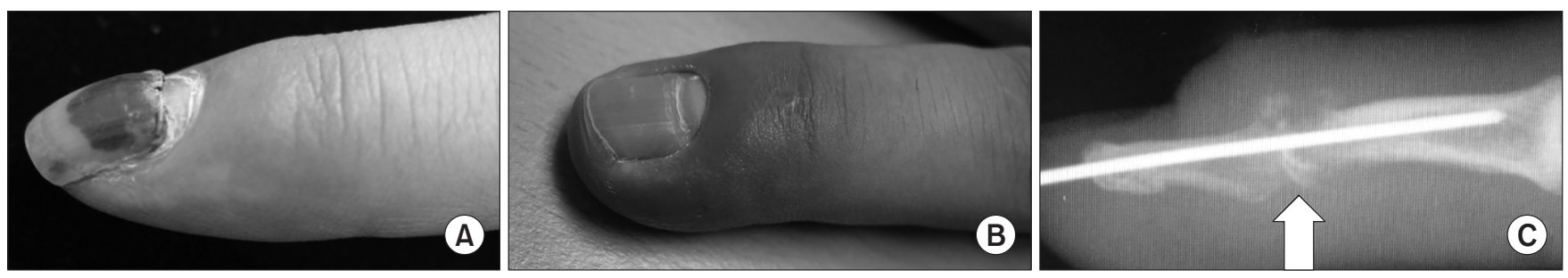

Figure 4. Complications of operative treatment for mallet fractures of the distal phalanx. (A) Nail deformity. (B) Skin infection. (C) Osteomyelitis after operative treatment for a mallet fracture.

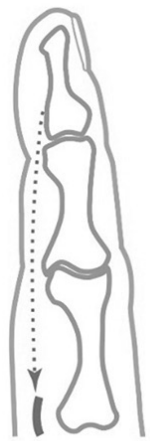

Type I

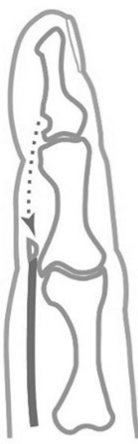

Type II

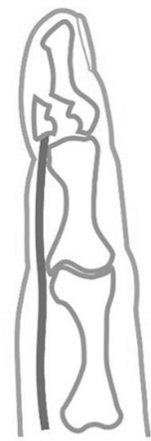

Type III

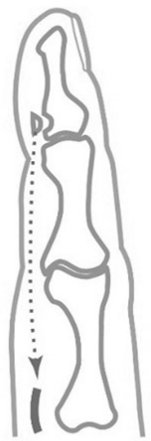

Type IV

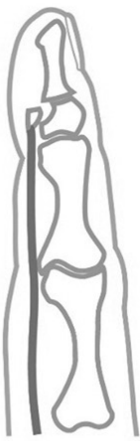

Type Va

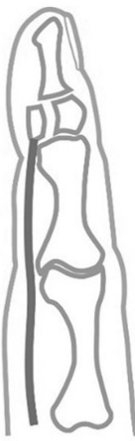

Type Vb

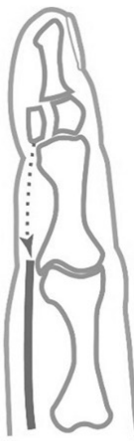

Type Vc
Figure 5. Al-Qattan's extended classification of flexor digitorum profundus tendon avulsion injuries.
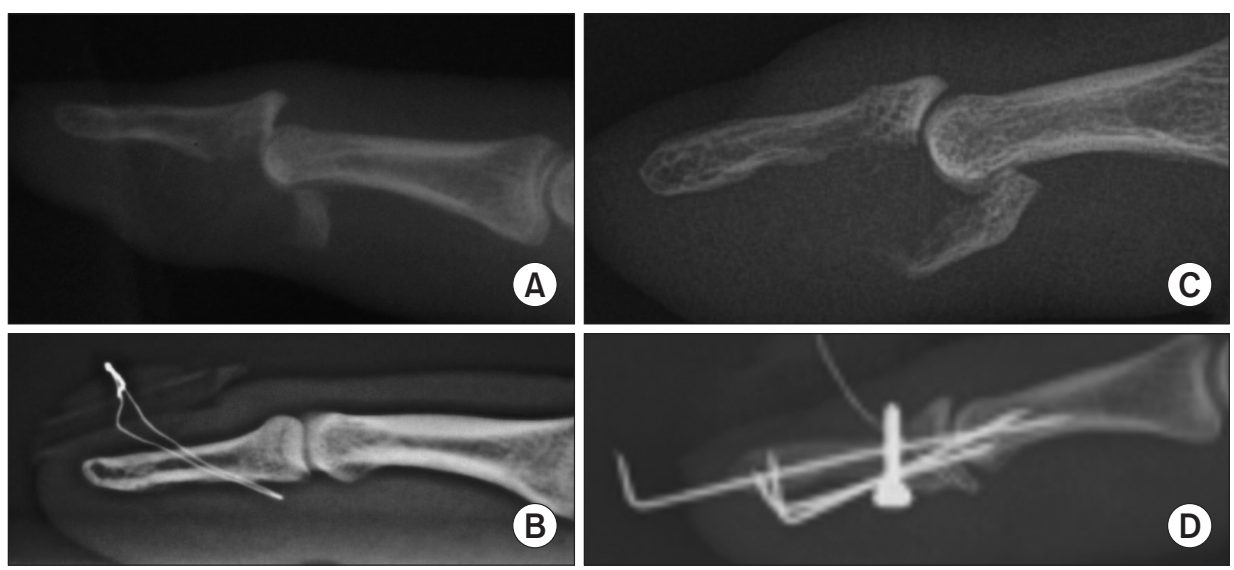

Figure 6. Different methods of repair for flexor digitorum profundus (FDP) avulsion injuries. (A, B) Pull-out wire fixation for a small bony fragment in a type III FDP avulsion fracture. (C, D) Screw fixation for large bony fragment and additional transarticular pinning and pull-out wire fixation in type III FDP avulsion fracture. 
anchor) 등을 이용하여 봉합하며, 견열된 골편이 큰 경우( 3,5 형) $\mathrm{K}$-강선, 소형나사, 소형금속판을 이용하여 고정할 수 있다(Fig. 6). ${ }^{10)}$

제 5형과 같이 심수지굴건의 견열과 원위지골 간부 및 관절내 골절이 동반된 경우에 경관절고정을 통한 안정된 고정유지와 관 절면의 정확한 정복이 중요하다(Fig. 7).

수술 후 고정의 실패나 외상성 관절염 등의 합병증 발생 가능 성이 높다. 치료가 지연된 만성 견열 손상의 경우에는 환자의 여 러 요인들을 고려하여 간과(skillful neglect)하는 보존적 치료, 종지 건 박리술 및 건의 원위부 전진 봉합술(advancement of terminal tendon), 단계적 건 재건술, 원위지간관절의 유합술 등 의 치료를 할 수 있다.

\section{2. 근위지간 관절 손상}

먼저 관절 내 골절인 근위지골의 과(condyle) 골절 치료에 대해 서 논의하고, 근위지간 관절의 골절-탈구를 손상 기전에 따라 분
류하여 치료의 접근 방법을 논의하고자 한다.

\section{1) 과 골절}

과 골절은 주로 스포츠 손상이나 접촉 손상으로 발생하여 젊은 연령층에서 호발한다. 한쪽 과(unicondyle) 골절인 경우 전후면 과 측면 방사선 사진에서는 간과되기 쉬우므로 사면 촬영이 진단 에 있어서 필수적이다. 비 전위 과 골절의 경우, 추시 관찰 중에 전위가 발생하는 경우가 많아서 첫 3주간은 면밀한 추시 관찰이 필요하다. 대부분은 사상 골절(oblique fracture) 형태의 불안정 골절로 안정된 고정이 필요하다. 적절히 치료하지 않으면 부정 유합으로 인한 각변형, 회전 변형과 관절면 부조화로 인한 관절 염이 발생할 가능성이 높다. 전위된 과 골절은 측면 접근 혹은 배 측 접근을 통해 골편을 $\mathrm{K}$-강선이나 나사를 이용해 내고정을 시 행한다. 양측 과 골절 또는 분쇄형 관절내 골절은 내고정이 쉽지 않으며, 내고정이 불가능한 경우는 외고정 장치를 이용한 수술방 법이 사용된다. 과 골절 수술 후 굴곡 구축이 종종 발생할 수
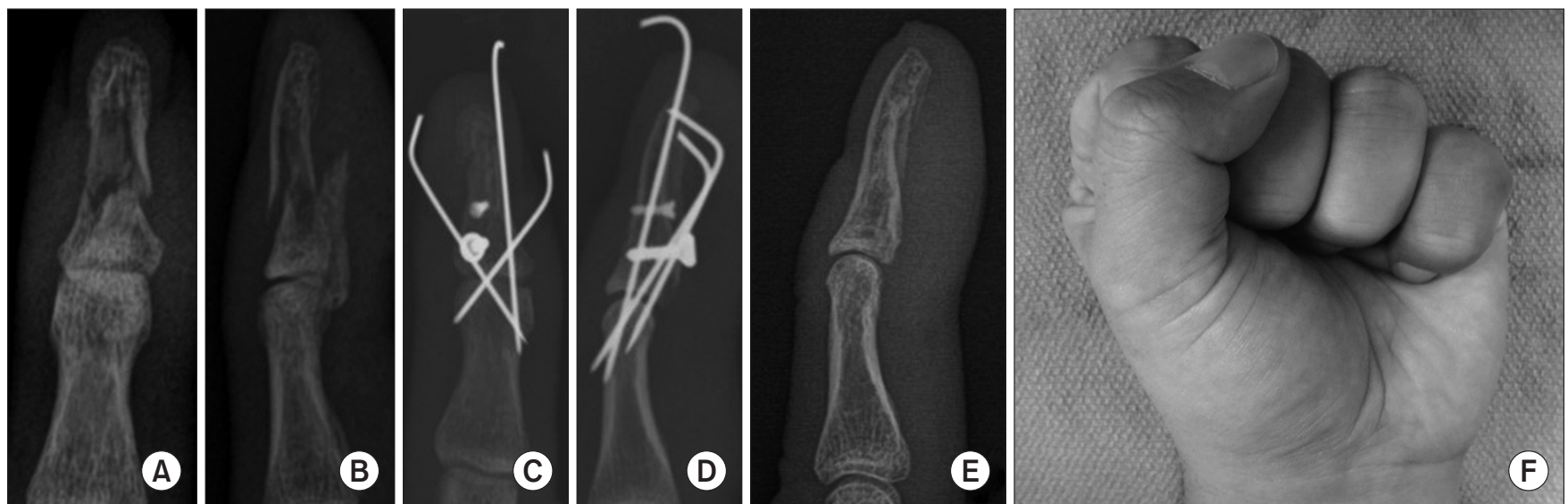

Figure 7. Fixation of an avulsed bony fragment using screws after trans-articular pinning of the distal interphalangeal (DIP) joint in type $V$ flexor digitorum profundus (FDP) avulsion injury. (A, B) Fracture of the distal phalanx and a concomitant avulsion fragment caused by the FDP (Type Vb). (C, D) Kirschner's wires were inserted in a crisscross direction to fix the DIP joint, and screws were inserted to fix the avulsed bony fragment. (E) Longterm follow-up shows solid bone union and excellent joint congruity. (F) The final active range of motion of the 5th finger included intact flexion and extension.
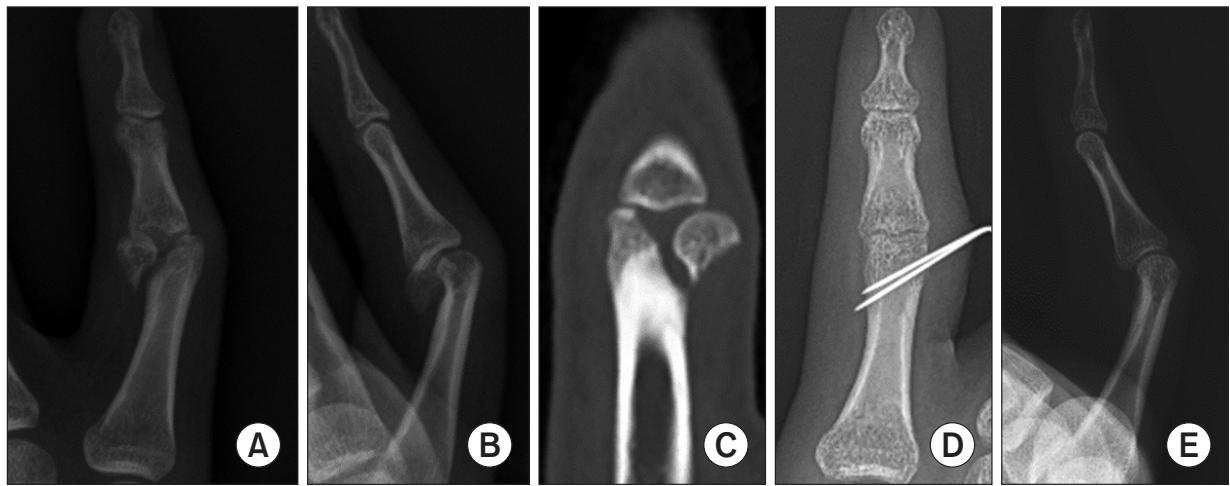

Figure 8. Internal fixation using K-wires for an unstable condylar fracture of the proximal phalanx. (A, B) Displaced condylar fracture. (C) Computed tomography scan showed a rotated condylar fragment. (D) Two K-wire fixation using a lateral approach. (E) Postoperative radiograph six months after surgery show a united fracture with mild flexion contracture. 
Ho Jung Kang and Ji Sup Kim

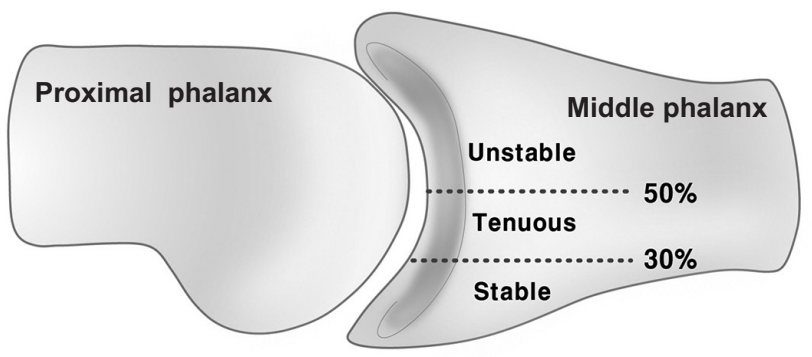

Figure 9. Proximal interphalangeal joint stability depends on the amount of intact articular surface.
있다(Fig. 8). ${ }^{11)}$

\section{2) 근위지 관절 골절-탈구}

근위지 관절의 골절-탈구는 대부분 불안정 형태로 나타나며, 적 절히 치료하지 않으면 관절 강직과 외상 후 관절염으로 진행하게 된다. 따라서 환자에게 치료 후 예상되는 결과, 수술 후 재활의 중 요성 및 잠재적 합병증에 관해 적절한 상담이 요구된다. 골절 탈 구 발생 후 근위지 관절의 안정성은 손상되지 않은 관절면의 양 에 따라 결정된다. 관절면의 $30 \%$ 이하를 포함하는 골절은 대부 분 안정적인 반면, $50 \%$ 이상의 골절에서는 불안정할 가능성이 매우 높다. ${ }^{12)} 30 \%$ 에서 $50 \%$ 사이의 관절면 손상의 경우는 어중간
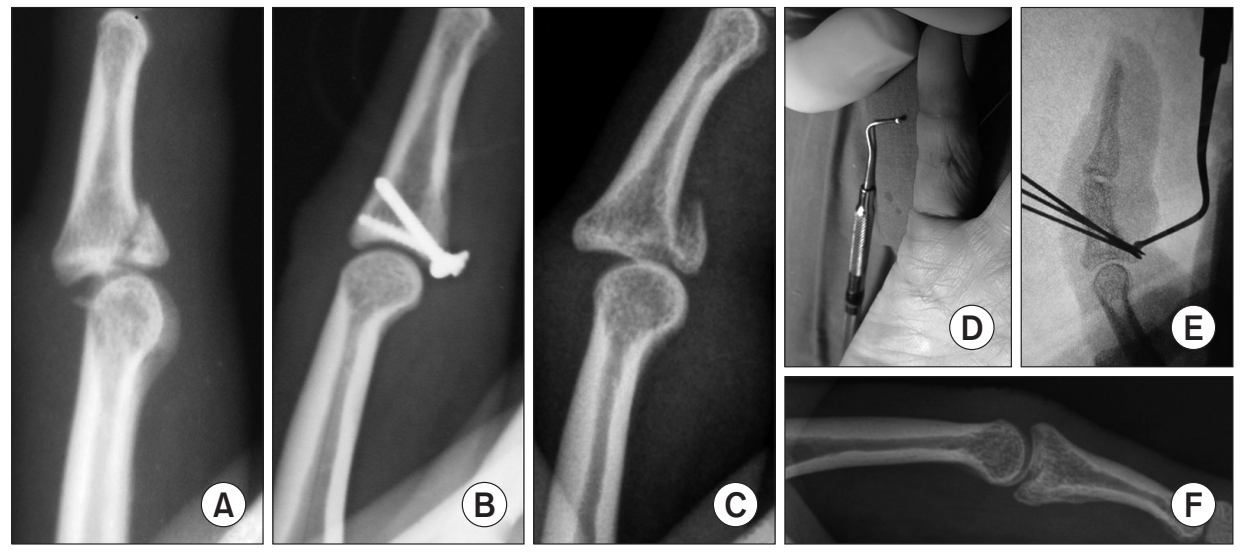

Figure 10. Open reduction and internal fixation with screw or K-wires for a dorsal fracture dislocation of the proximal interphalangeal (PIP) joint. (A, B) Screw fixation is most applicable to cases where there is one large volar lip fragment in a dorsal fracture dislocation of the PIP joint. Preoperative lateral radiograph and lateral radiograph six months after surgery show a united fracture. (C) This lateral radiograph shows a volar lip avulsion fracture and dorsal subluxation of the joint. $(\mathrm{D}, \mathrm{E})$ Minimally invasive fracture reduction technique using a dental probe through a small volar incision, and percutaneous K-wires fixation. (F) Lateral radiograph three months after surgery show a united fracture.
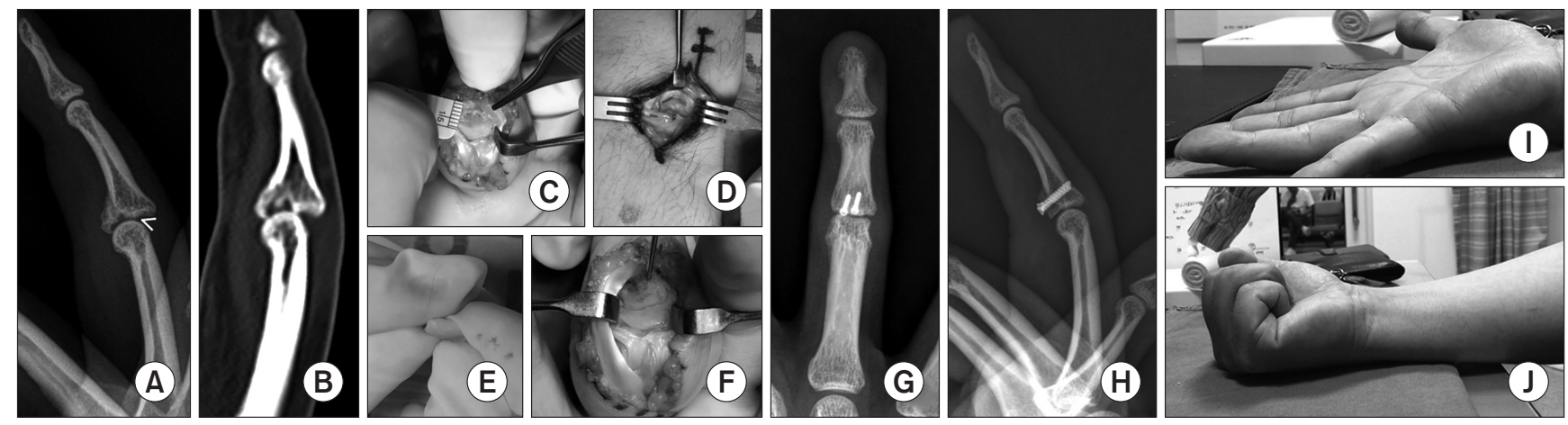

Figure 11. Surgical techniques of hemi-hamate arthroplasty. A 32-year-old man suffered a dorsal fracture dislocation of the proximal interphalangeal (PIP) joint in the right 4th finger two months ago. (A) Radiograph and (B) computed tomography scan image showing comminution with $50 \%$ articular involvement and dorsal subluxation. (C) The PIP joint was hyperextended by a shotgun style, the base of the middle phalanx was then completely exposed. (D) Distal hamate donor site with bases of the ring and small metacarpals exposed. (E) It is recommended that the graft be slightly oversized in all planes to allow for appropriate contouring. $(F, G)$ The graft was fixed firmly with two bicortical screws. (H) Latest follow-up (2 years after surgery) lateral radiograph demonstrating good congruency of PIP joint. (l, J) Range of motion of the reconstructed PIP joint was satisfactory. 
한 안정도(tenous stability)를 가진 골절로 불안정성 전위나 탈 구의 발생 가능성이 있으므로 치료 시 안정성에 대해서 신중하게 평가해야 한다(Fig. 9).
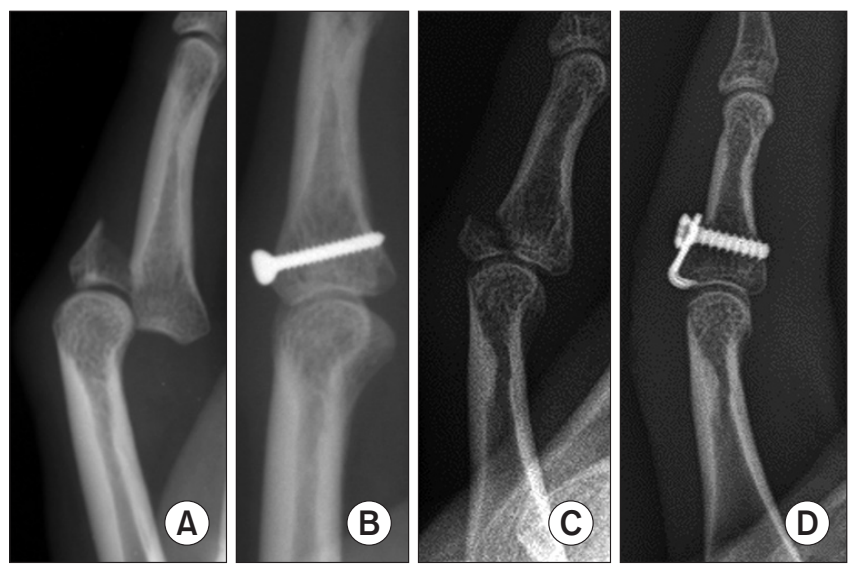

Figure 12. Fixation techniques for a volar fracture-dislocation of the proximal interphalangeal joint. (A) Lateral radiograph showing dorsal lip fracture with volar subluxation. (B) Large displaced fractures could be stabilized with a screw. (C) Radiograph showing that the extensor central slip was avulsed with a small bone fragment from the dorsal lip of the base of the middle phalanx. (D) Radiograph showing a small fracture fragment secured to the hook plate and screw.
(1) 배측 골절 탈구

과신전 손상기전으로 발생하며, 대부분은 중위지골 기저부 수장 판 견열 골절 형태로 발생된다. 간단 배측 탈구인 경우, 쉽게 정복 이 가능하며, 위의 언급된 대로 손상된 관절면의 정도에 따라서 관절의 안정성이 결정된다. 아탈구 등의 불안정성이 없는 작은 골절편은 수술적인 고정 없이 신전제한 부목을 통한 조기 관절운 동을 통해 좋은 결과를 보인다. 아탈구 여부는 측면 방사선 사진 에서 근위지골 골두의 관절면과 손상 받지 않은 중위지골 관절면 의 V자형의 간극을 관찰하여 확인할 수 있다(V-sign).

골편의 크기, 분쇄의 정도, 급성 또는 만성 등에 따라서 수술적 치료 방법이 결정되는데 신전 제한 핀 고정술, ${ }^{13)}$ 관혈적 정복과 금속판, 나사 또는 $\mathrm{K}$-강선을 이용한 고정술(Fig. 10), 동적 외고 정술 ${ }^{14)}$ 등이 사용된다.

이러한 방법으로 불안정성의 해결이 안되는 경우에는 신전 수 장판 관절성형술이나 반-유구골 관절성형술 ${ }^{15)}$ 이 사용된다(Fig. 11). 반-유구골 관절성형술(hemi-hamate arthroplasty)은 급성 과 만성 손상 모두에서 사용될 수 있으며, 공여부의 부작용이 거 의 없고 70도 이상의 능동적 관절운동을 회복할 수 있는 장점이 있는 반면 기술적으로 쉽지 않다는 단점이 있다.

(2) 수장측 골절탈구

배측 골절탈구보다는 드물게 발생하지만 적절한 치료를 하지 않 으면 임상적으로 합병증이 발생할 가능성이 매우 높다. 골절부의
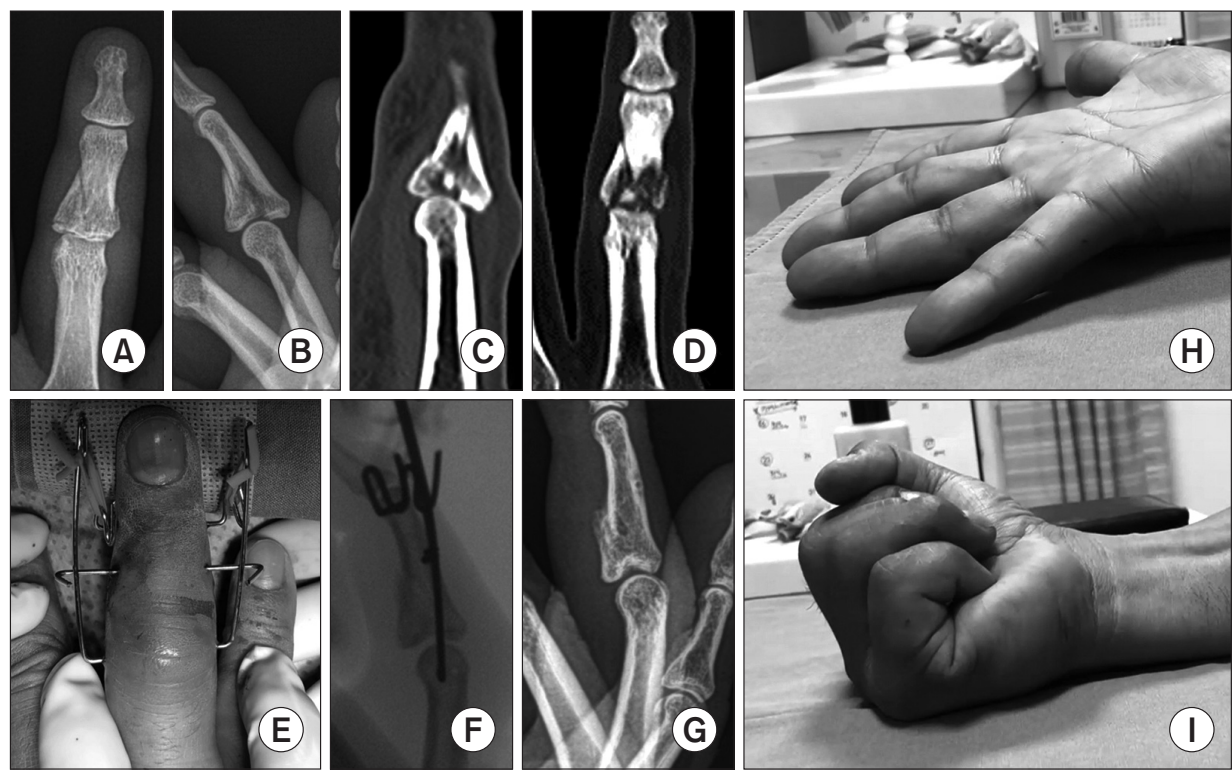

Figure 13. Dynamic external fixation using pins and rubber bands for pilon fractures of the proximal interphalangeal (PIP) joint. Dynamic external fixator holds the PIP joint to length and allows early active motion while healing. This is especially useful for severe comminuted fractures where internal fixation may be impossible. (A) Anteroposterior and (B) lateral radiographs and (C, D) computed tomography scan images showing pilon fracture of the proximal. (E) Dynamic external fixation using pins and rubber bands. (F) Intraoperative lateral c-arm views after a dynamic external fixator showing no subluxation and reduction of an intra-articular fracture. (G) Lateral X-ray films one year after injury showing consolidation of the fracture fragments and articular remodeling. $(\mathrm{H}, \mathrm{I})$ The follow-up shows excellent flexion interphalangeal joint. 
크기가 작더라도 파열된 신건으로 인해 단추 구멍 변형(boutonniere deformity)이 유발될 가능성이 높기 때문이다. 탈구 정복 후 수지 신전 시 안정성이 유지되면 보존적 치료를 할 수 있으나 전위가 있고, 골편의 크기가 큰 경우 고정이 요구된다(Fig. 12).

(3) Pilon 골절

중위지골 기저부의 관절면의 분쇄 골절과 동반되어 배측 및 수장 측의 골 지지가 손상된 경우를 말한다. 축 하중 손상(axial load mechanism)으로 발생하여 관절 면 중심부의 감입소견이 특징 적이다. 대부분의 경우, 관혈적 정복을 통해 관절면의 해부학적 정복이 어렵다. 관절의 재형성(articular remodeling)을 노린 동
적인 외고정 장치를 사용하여 통해 비교적 양호한 결과가 보고되 고 있다(Fig. 13). ${ }^{14)}$

\section{3. 중수지관절 손상}

제 2-5 중수지 관절 손상은 발생빈도가 무지에 비해 드물다. 탈 구는 후방 탈구가 가장 흔하며, 과신전 손상으로 발생한다. 복합 후방 탈구로서 골두가 원위부로 수영인대와 수장판, 근위부로 수 장 건막 횡인대, 척측으로 수지굴건, 요측으로 충양근에 둘러싸 여 정복이 되지 않을 경우를 Kaplan 병변이라고 하며 관혈적 정 복을 요하는 경우가 대부분이다. 수장측과 배측으로 관혈적 정복
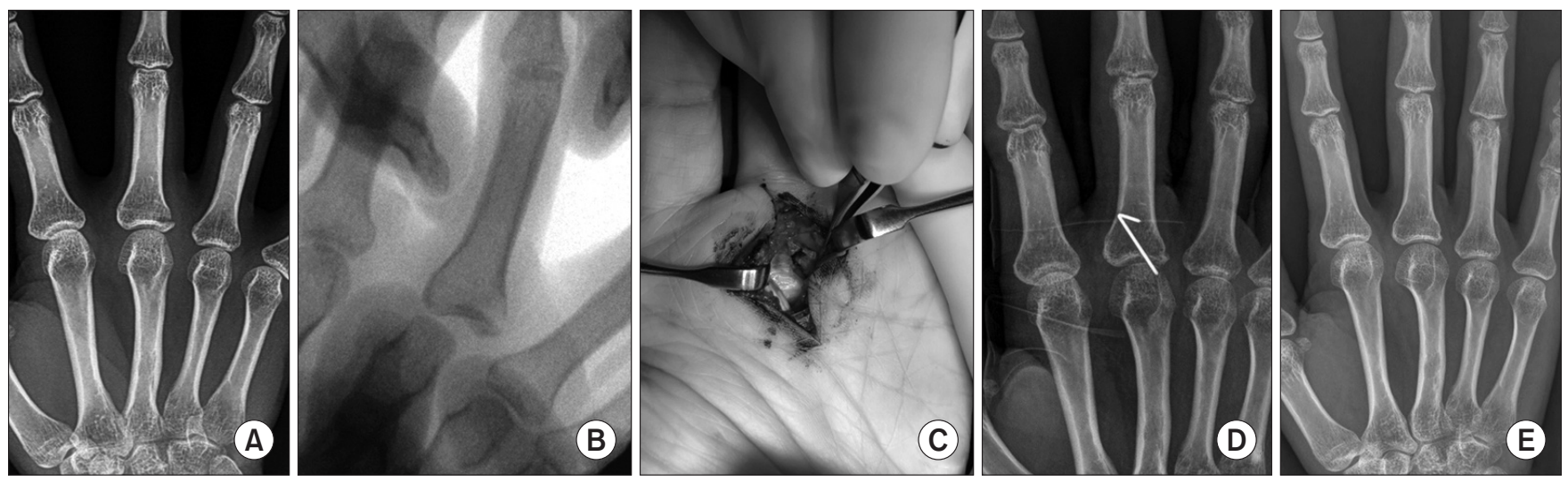

Figure 14. Volar A1 pulley approach for fixation of avulsion fractures of the base of the proximal phalanx. (A) Anteroposterior radiograph of a patient, who sustained an avulsion fracture at the ulnar base of the proximal phalanx of the middle finger. (B) Assessment of the stability of the ulnar collateral ligament demonstrates instability with stress. (C) The avulsion fragment from the proximal phalanx and its attachment to the collateral ligament were identified using the volar approach. (D) Open reduction and fixation of avulsed fracture fragment using K-wire. (E) Anteroposterior radiograph six months after surgery show a united fracture.
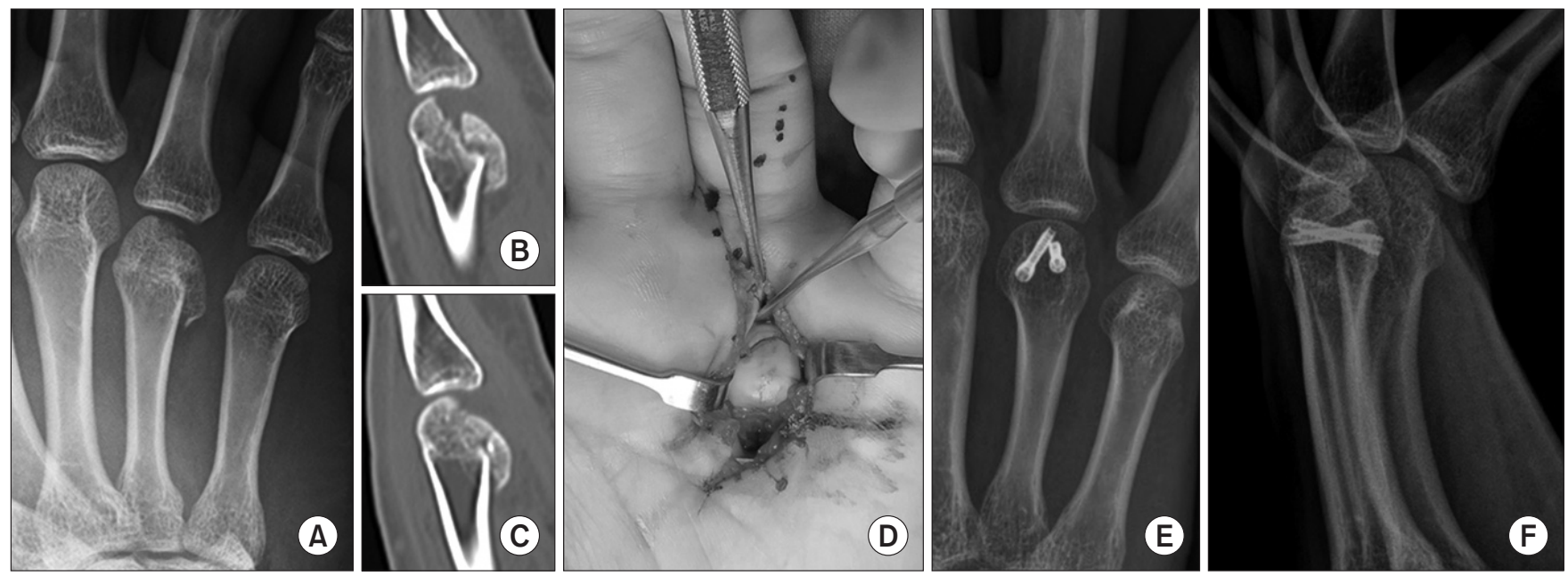

Figure 15. Screws fixation for a fracture of the head of the metacarpal bone. (A) Oblique radiograph and (B, C) computed tomography scans showed an intra-articular fracture of the 4th metacarpal head. (D) Reduction of fracture fragment using the volar approach. (E) Anteroposterior and (F) lateral radiographs six months after surgery show a united fracture. 
The Current Concepts in Treatment of Fracture-Dislocations of the Finger

이 가능하나 수장측 접근법의 경우에 수장판, 수영인대 및 수장 건막횡인대 절개를 순차적으로 가하여 정복할 수 있다. 전방 접 근법은 병변으로 직접 접근이 가능하고, 관절의 해부학적 정복이 용이하며, 파열된 수장판의 복구가 가능하여 술 후 불안정성의 위험이 적다는 장점이 있다.

중수지 관절에서 발생하는 측부인대의 견열 골절과 중수골두 의 골절의 치료에 대해 언급하고, 추가로 무지의 중수지관절의 손상에 대해서 기술한다.

\section{1) 근위지골 측부인대 견열 골절}

척골 측부인대 견열골절 비교적 흔히 발생하는 무지와 다르게 제 2-5 중수지 관절의 측부인대 견열 골절은 드물다. 스트레스 검 사에서 건측과 비교해서 불안정성이 심한 경우, 견열 골편이 회 전 전위된 경우, 관절면의 $20 \%$ 이상을 차지하는 전위 골편의 경 우는 수술적 치료를 고려한다. 골편 고정 시 이용되는 접근 방법 은 배측을 통한 접근이 일반적이다. 하지만, 견열골절은 측부인
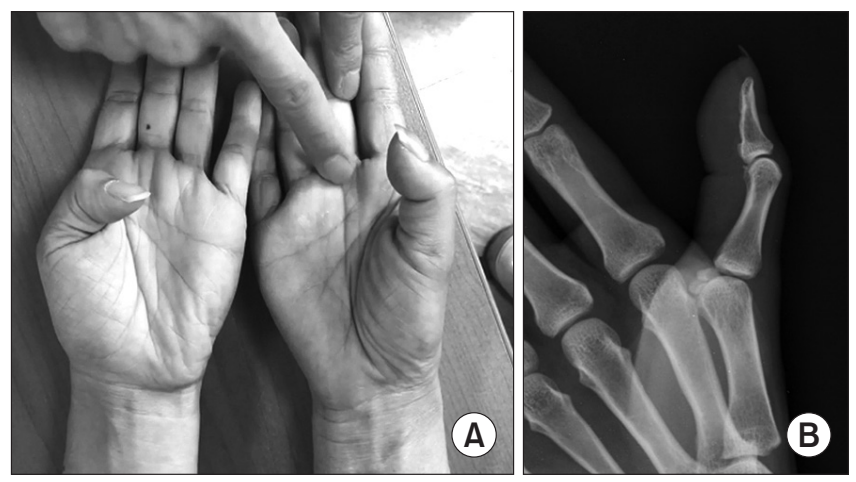

Figure 16. Metacarpophalangeal (MP) joint locking of the thumb after hyperextension injury. (A) A 40-year-old woman with a characteristic deformity of a mildly hyperextended MP joint of the right thumb and an inability to flex the joint either actively or passively. At the interphalangeal joint, the thumb was mildly flexed but could not be actively flexed or extended. (B) The lateral radiograph of the injured thumbs showed a hyperextension of the MP joint without dorsal subluxation.
대의 해부학적 위치상 근위지골의 수장측에서 발생하므로 배측 으로 접근하기가 어렵다는 단점이 있어, 수장측 접근(A1 volar approach)이 선호되기도 한다(Fig. 14). ${ }^{16)}$

\section{2) 중수골두 골절}

드물게 발생하나 치료하기 어려운 골절로서 관절면의 전위가 1 $\mathrm{mm}$ 이상인 경우 수술적 치료가 필요하다. 분쇄가 심하지 않은 경우 소형 나사못이나 흡수 핀이나 흡수 고정나사(absorbable pin or screw), 혹은 무두나사(headless screw) 등을 이용한 내 고정 방법과 조기 관절운동을 통해서 좋은 결과를 얻을 수 있다 (Fig. 15). 분쇄가 심한 경우 외고정 장치를 사용하거나, 도수정복 후 $\mathrm{K}$-강선 고정을 시도할 수 있다.

\section{4. 무지의 중수지관절 손상}

무지 중수지관절의 가장 흔한 손상은 과신전 손상이며, 다음으로 는 외전력에 의한 척측 측부인대 손상이 흔하다. 과신전 손상 후 중수지관절의 아탈구에 의해서 관절이 구부러지거나 펴지지 않 는 잠김(locking) 상태를 보이기도 한다. ${ }^{17)}$ 방사선 영상에서 중수 지관절의 경한 과 신전 변형이 있으면서, 중수지관절의 수동, 능 동적 굴곡이 불가능한 점이 특징적이다(Fig. 16).

탈구 시에는 도수정복을 시행하게 되는데 과도한 종적 견인은 골절이 유발될 수 있으므로 주의해야 한다. 손목과 지간관절이 굴곡된 상태로 굴곡건을 이완시킨 다음, 근위지골의 기저부를 배 측에서 수장측으로 직접압력을 가하여 도수정복을 시행한다. 도 수정복 후에는 측부인대 손상 여부를 반드시 확인해야 한다. 도 수정복이 불가능한 경우, 정복 후 무지내전근이나 단무지 굴곡근 파열이 동반된 경우, 척측 측부인대 파열이 완전히 파열되어 심 한 불안정성이 있는 경우는 관혈적 정복 등의 수술적 치료를 시 행한다.

1) 무지 근위지골 측부인대 견열 골절

무지 중수지 관절의 인대 손상 중 척측 측부인대 손상이 $58 \%$ $90 \%$ 정도로 요골측 측부인대보다 발생빈도가 높다. 골절편이 작
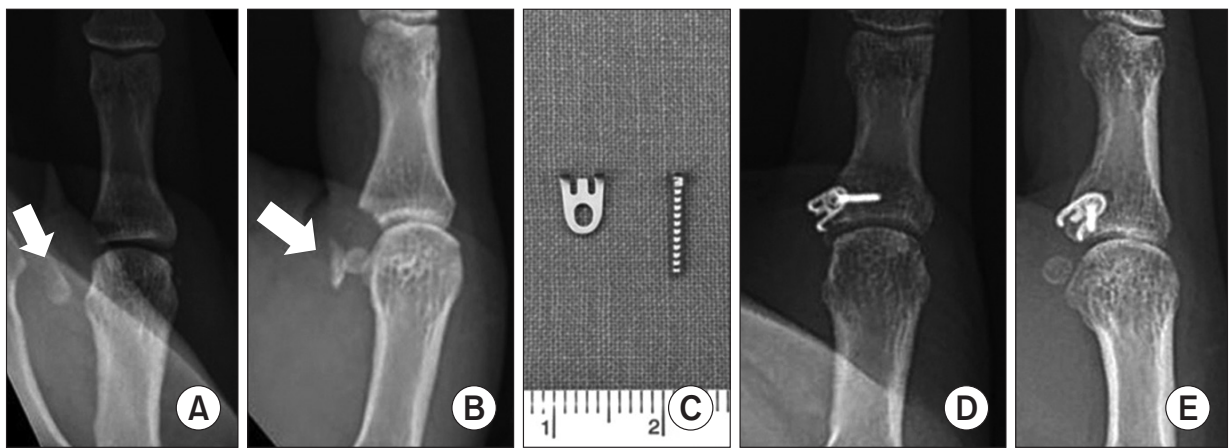

Figure 17. Hook plate fixation for the thumb ulnar collateral ligament avulsion fracture. (A, B) Radiographs demonstrating bony avulsion of the ulnar collateral ligament (arrows). (C) The 1.2-mm titanium hook plate and cortical screw. (D, E) Postoperative images showed stable fixation of the bone fragment using a mini hook plate. 
거나 전위가 $2 \mathrm{~mm}$ 이하인 경우 보존적 치료를 할 수 있다. 하 지만 척측 측부인대 손상으로 인한 만성 불안정성은 집기 동작 (pinch)의 어려움을 줄 수 있어 전위가 $2 \mathrm{~mm}$ 이상인 경우 수술 적 치료가 필요하다. 보통 관절면의 $20 \%$ 이상의 골편의 경우 관 혈적 정복 및 금속나사, 소형 갈고리 금속판(mini hook plate) 나 $\mathrm{K}$-강선을 이용한 내고정술이 필요하며, 골편이 작아 고정이 불가능한 경우에는 골편을 제거하고 인대를 소형 고정나사(mini suture anchor)을 이용하여 부착시킬 수 있다(Fig. 17).

파열된 척측 측부인대의 사이에 adductor aponeurosis가 삽 입되는 경우를 Stener 병변이라 하며, 파열된 측부인대가 전위되 어 있어 보존적인 방법으로는 치유가 진행되지 않아 수술적인 치 료를 요한다.

\section{5. 무지 중수골 기저부 골절}

제 1 수지 수근 중수간 관절은 수부관절 중 가장 운동범위가 큰 관절로, 손상 시 현저한 수부 기능장애를 초래할 수 있으므로 그 치료에 주의가 필요하다. 무지 중수골 기저부 골절에서 가장 흔 한 골절은 베네트씨 탈구 골절(Bennett's fracture-dislocation) 이다. 무지 중수골 관절내 골절로 대부분 불안정하며, 전방사선 인대에 고정된 전내측 골편에 대해서 중수골 간부가 장무지외전 근에 의해 외측 근위부로, 무지 내전근에 내측으로 당겨져 요배 측 전위가 발생하게 된다. 관절의 침범 및 불안정성으로 인해 대 부분의 경우에서 수술적 치료로 도수정복 및 경피적 핀고정술 (closed reduction and percutaneous pinning)을 요한다. 비관 혈적 정복 후에도 골편의 회전 변형이나 전위 혹은 관절면의 불 규칙이 $2 \mathrm{~mm}$ 를 초과 시에는 관혈적 정복이 요구된다(Fig. 18).

$\mathrm{T}$ 또는 $\mathrm{Y}$ 자 형태의 관절면 전체를 포함한 골절인 롤란도씨 탈 구 골절(Rolando's fracture-dislocation)은 관절면의 복잡 골
절까지 그 의미가 확대되었다. 가급적 관절면의 해부학적 정복을 시도하여 외상성 관절염을 피해야 한다. 하지만 골절편의 크기가 큰 경우는 관혈적 정복에 의한 해부학적 정복을 시행할 수 있으 나 분쇄가 심한 경우에는 관혈적 정복 시 작은 골편들로 인해 내 고정이 어렵고 관혈적 정복이 도수정복보다 못한 결과를 보이기 도 하므로 치료 방법 결정에 주의를 기울여야 한다. 분쇄가 심한 골편의 관혈적 정복 시에는 술 후 재 전위 방지를 위해 외고정 장 치를 추가적으로 사용할 수 있으며, 내고정은 골편의 크기에 따 라 금속나사와 금속판 고정 및 $\mathrm{K}$-강선을 이용하고 심한 골결손 시 골이식을 시행하기도 한다(Fig. 19). ${ }^{18)}$
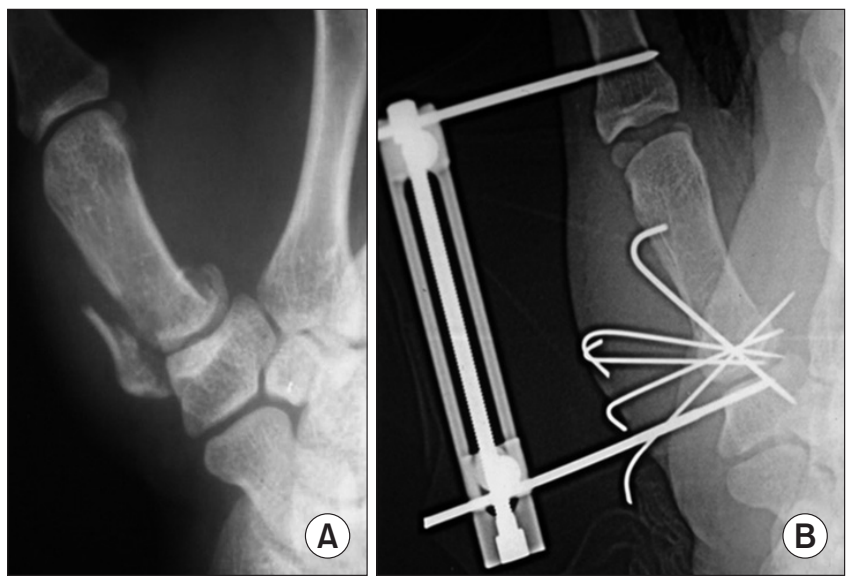

Figure 19. External fixation technique for a comminuted intra-articular fracture of the base of the 1st metacarpal bone. (A) First metacarpal base intra-articular comminuted fracture. Comminution is very severe. (B) The fracture was treated with limited open reduction and internal fixation with multiple K-wires and the application of an external fixator.
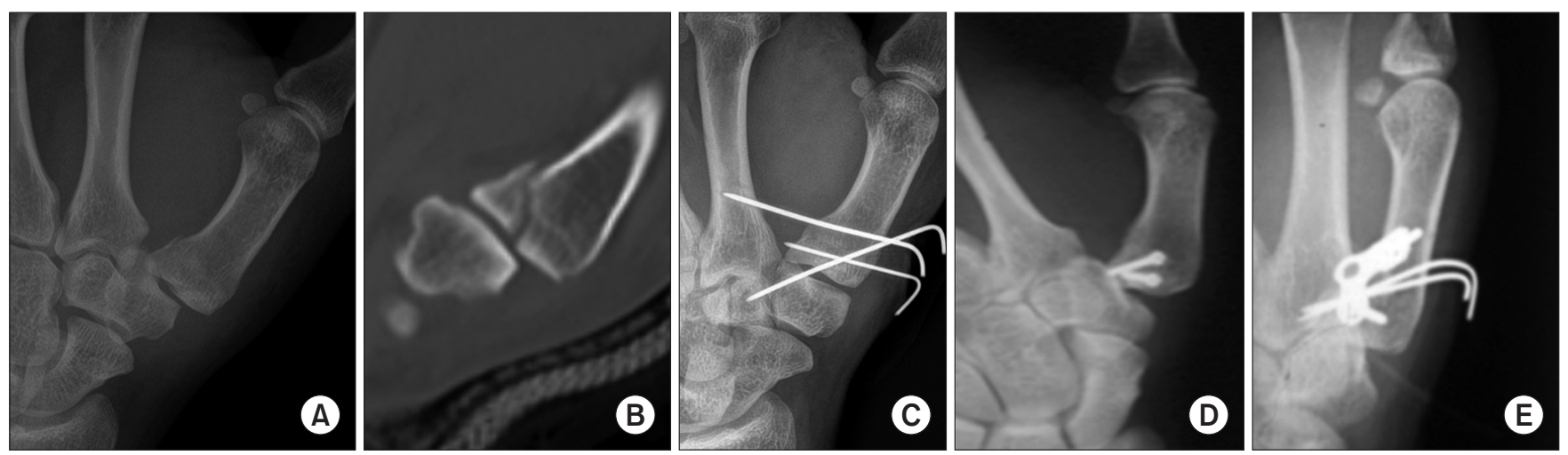

Figure 18. Various methods for the fixation of fractures of the base of the thumb metacarpal. (A) First metacarpal base intraarticular fracture was observed on the radiograph and (B) computed tomography image. (C-E) After achieving a satisfactory reduction with the closed method, K-wire fixation was performed. If the fragment is large, a lag screw is placed from dorsal to volar for rigid fixation. The fracture was treated with two lag screws placed from the dorsal to volar. In a Rolando fracture, fracture with shaft extension was treated with a plate, and the small fragment was fixed with two K-wires. 
The Current Concepts in Treatment of Fracture-Dislocations of the Finger

6. 수지 골절 탈구 치료의 합병증

골절 후 합병증은 보존적 치료나 수술적 치료 모두에서 발생 가 능하며, 관절의 강직, 부정 유합, 불유합, 감염 등이 있다. 이 중 관 절 운동의 부분적 제한이 가장 흔하다.

\section{1) 강직}

근위지간관절 손상 후 굴곡 구축(flexion contracture)이 흔하 게 발생한다. 15 도에서 20 도의 부분적 굴곡구축은 대부분의 환 자에서 기능적인 문제가 되지 않으나 이보다 더 심한 각도의 구 축은 지속적인 물리치료, 도수치료 혹은 보조기 착용 및 수술적 치료가 필요할 수 있다. 수술적 치료 시 구축의 주된 원인으로 작 용하는 checkrein 인대의 유리술이 중요하다. 일단 강직이 발생
하면 2차적인 치료에도 불구하고 완전한 관절 운동 회복이 어려 운 경우가 많다. 따라서 강직의 예방이 무엇보다 중요하며, 정확 한 관절면의 정복 및 안정된 고정 이후 조기 관절운동이 이루어 져야 한다. 치료는 초기 손상의 기전, 정도, 수상 후 기간, 초기 치 료 방법과 재활방법 및 환자의 직업 등을 자세히 조사하고, 피부 나 근막, 건, 관절막이나 인대, 관절면 손상 등 여려 원인으로 강 직이 발생 가능하므로, 이에 대한 세심한 진찰, 초음파 검사, 필요 시 자기공명영상(magnetic resonance imaging) 검사를 이용하 여 원인 파악 및 그에 따른 적절한 치료가 요구된다(Fig. 20).

\section{2) 부정 유합 및 불유합}

부정 유합은 주로 골절의 비 수술적 치료 후 주의 깊은 추시 관찰
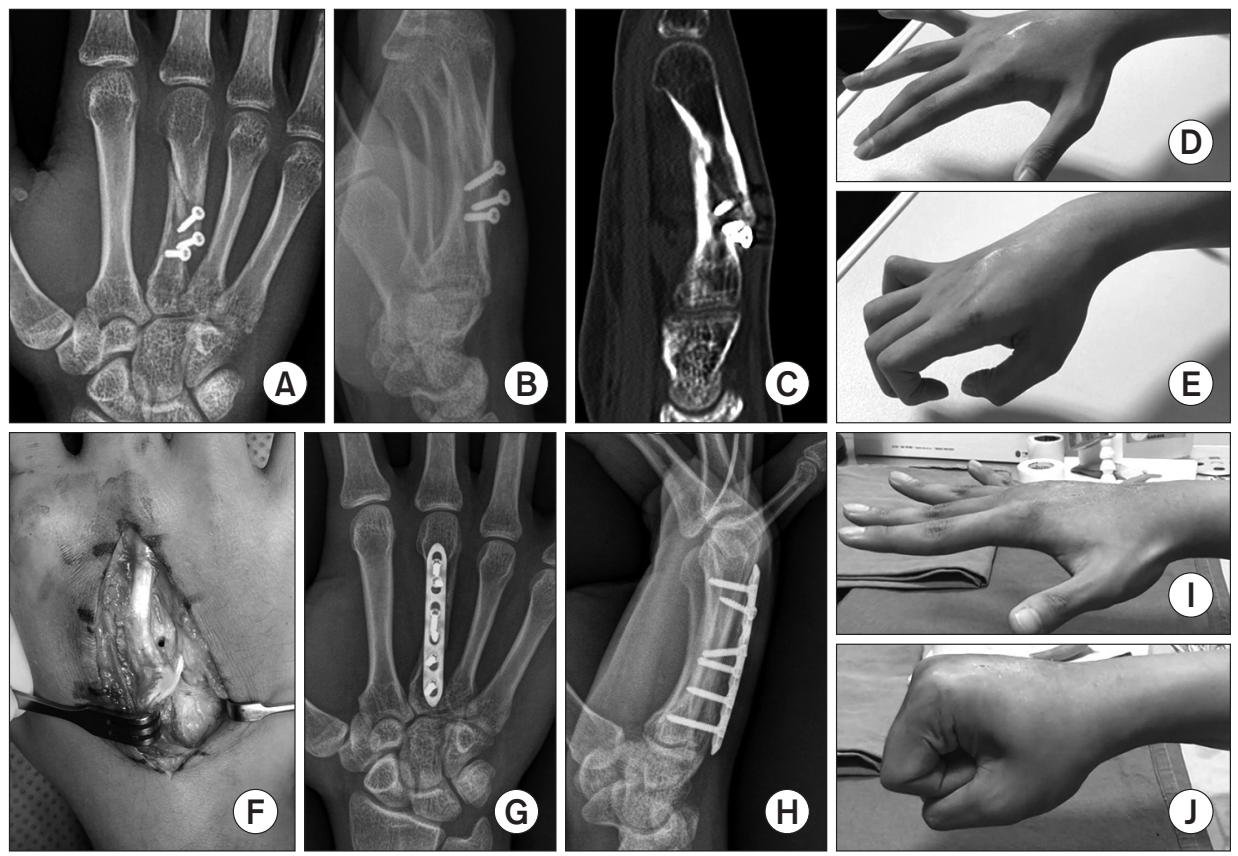

Figure 20. Stiffness associated with malunion after failed fixation for a metacarpal shaft fracture. (A, B) Radiographs taken five months after metacarpal shaft fracture; callus formation in the state of fixation failure. (C) Dorsal angulated metacarpal shaft malunion. (D, E) Preoperative stiffness as the metacarpophalangeal joint. (F) After screws removal, extensor tenolysis was performed. $(G, H)$ Correctional osteotomy and fracture site were stabilized with a locking plate. (I, J) Mobilization was begun two days after the operation, the range of motion at six months after surgery.
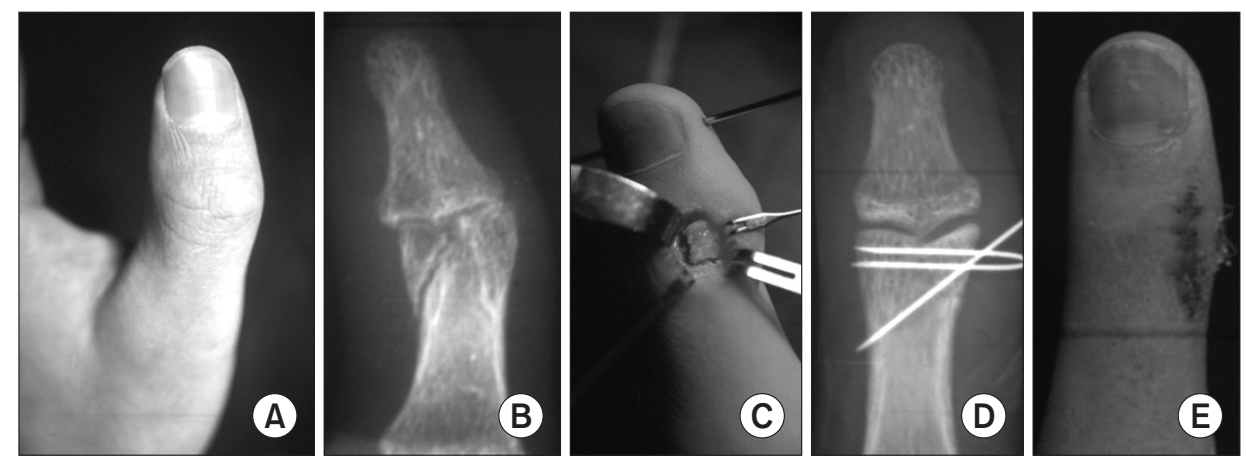

Figure 21. Correctional osteotomy for condylar malunion of the finger. (A) A 16-year-old man presented five months after injury to the left thumb with pain, stiffness, and angular deformity. (B) X-ray showed a malunited ulnar condyle of the proximal phalanx. (C) The radial condylar closed wedge osteotomy is performed with restoration of the joint congruity. (D) Stable fixation is achieved with 0.75 mm K-wires. (E) After two months after surgery, angular deformities were fully corrected. 
Ho Jung Kang and Ji Sup Kim

을 하지 않아서 발생한다. 회전 변형, 종적 및 외측 각형성, 단축 으로 분류된다. 부정 유합이 기능적인 제한, 통증, 파악력의 감소 를 유발하는 경우에 수술적 치료의 대상이 된다. 부정 유합된 부 위에서 절골술을 통해 교정한다(Fig. 21). 관절 내 부정 유합의 경 우 치료가 어렵다. 관절 외 절골술은 각변형을 교정할 수는 있으 나 관절면의 불일치를 해결할 수는 없으며, 관절 내 절골술은 관 절면의 정복이 가능하나 관절강을 열어야 하므로 추후 무혈성 괴 사나 관절의 강직이 발생할 가능성이 높다. ${ }^{19,20)}$ 불유합은 수지, 중수골 골절에서 드물게 발생하며, 연부조직 손상이 동반된 경우 발생 가능성이 높다. 대부분의 수지 및 중수골 골절은 3-6주만에 임상적으로 유합의 징후가 관찰된다. 임상적으로 초기 손상 이 후 4개월 이상 유합의 증거가 보이지 않으면, 추가 고정(immobilization) 기간에 발생할 수 있는 관절의 강직 발생 원인에 의 해 재수술이나 자가골 이식술 등을 이용한 견고한 골절고정(rigid fixation) 및 조기 관절 운동 치료가 요구된다. ${ }^{21)}$

\section{3) 변형}

백조목(swan neck deformity) 변형과 단추구멍 변형(boutonniere deformity)이 발생할 수 있다. 백조목 변형은 근위지간 관 절은 과신전, 원위지간 관절은 굴곡되는 변형으로, 추지 변형이 나 근위지 관절 수장판 손상으로 인해 이차적으로 발생할 수 있 다. 측부대(lateral band)의 후방 아탈구로 인해 근위지 관절의 굴곡이 제한되고 통증성 탄발(snapping)이 발생한다. 근위지간 관절의 유동성, 관절면의 상태에 따라 유형을 나눌 수 있고 정상 관절 운동을 보이며 구축이 없는 경우는 근위지간 관절 신전 제 한 부목이나 반지형 수지 부목(silver ring splint), 역동적 근위지 관절 보조기(dynamic proximal interphalangeal joint brace) 등을 먼저 시도해볼 수 있다. 보존적 치료가 실패했을 때 변형 및 통증이 심하고 관절 운동 제한이 심한 경우에는 근위지간 관절의
굴곡건 고정(flexor digitorum superficialis tenodesis), ${ }^{22)}$ 나선 경사인대 재건술(spiral oblique retinacular ligament reconstruction), 외측대 유리술(lateral band mobilization), 원위지 간 관절 유합술 등의 수술적 치료를 할 수 있다(Fig. 22). ${ }^{23)}$ 단추 구멍 변형은 원위지 관절은 과신전되고, 근위지 관절은 굴곡되는 변형으로 관절의 섬유화와 측부인대 및 수장판의 구축이 동반되 어 고정된 구축 상태인 경우에 수술적인 치료로 건 유리술 후 신 건 복원술 혹은 재건술 등을 시행할 수 있다. 원위지간 관절의 과 신전이 심한 경우, 말단 건절단술(terminal tenotomy)을 시행하 여 교정할 수 있다. ${ }^{24,25)}$

\section{4) 외상성 관절염}

관절 내 골절이나 관절의 불안정성, 변형이 지속되는 경우 외상 성 관절염이 발생할 수 있다. 보존적 치료가 실패 시 환자의 요구 나 선호도에 따라서 관절 치환술 혹은 관절 유합술을 고려할 수 있다. 하지만 관절의 유합술은 영구적인 관절 운동 소실을 유발 하므로 마지막에 고려해야 할 치료 방법이다. 골절의 분쇄가 심 하고 수술 후 골절 재전위가 있더라도 도수정복이나 신전 제한 핀고정술 등의 최소 절개 수술 및 보존적 치료로 관절면의 재형 성(remodeling) 가능성을 기대한다면 만족할 만한 결과를 얻을 수도 있다(Fig. 23). 관절 유합술은 통증을 경감시킬 수 있으며, 제 2 수지의 경우 일상생활을 위한 관절운동의 범위가 상대적으 로 작고, 관절 치환술시 실패율이 높기 때문에 관절 유합술을 먼 저 고려할 수 있다. 근위지 관절의 경우 제 2 수지가 40도 굴곡, 척측 수지 쪽으로 5도씩 증가시켜 고정한다(Fig. 24).

\section{요 약}

수부 골절은 흔한 골절로 정형외과 의사가 쉽게 접할 수 있다. 하
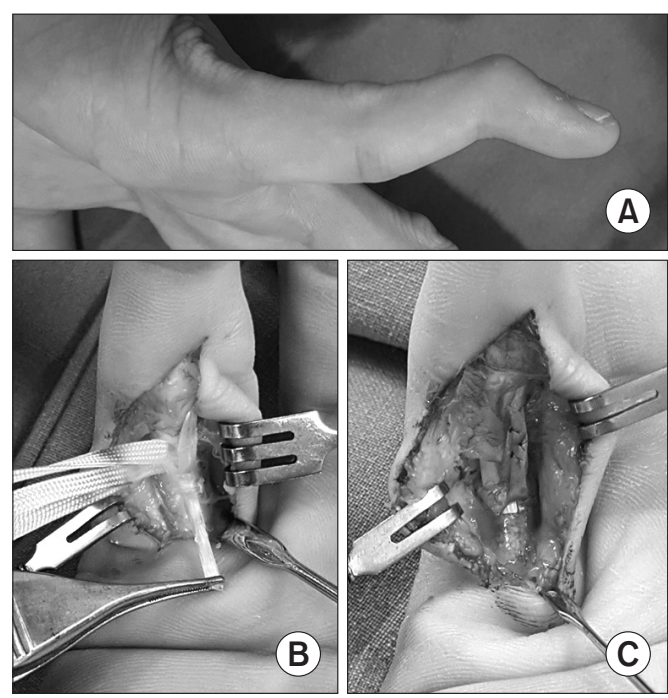

(A)
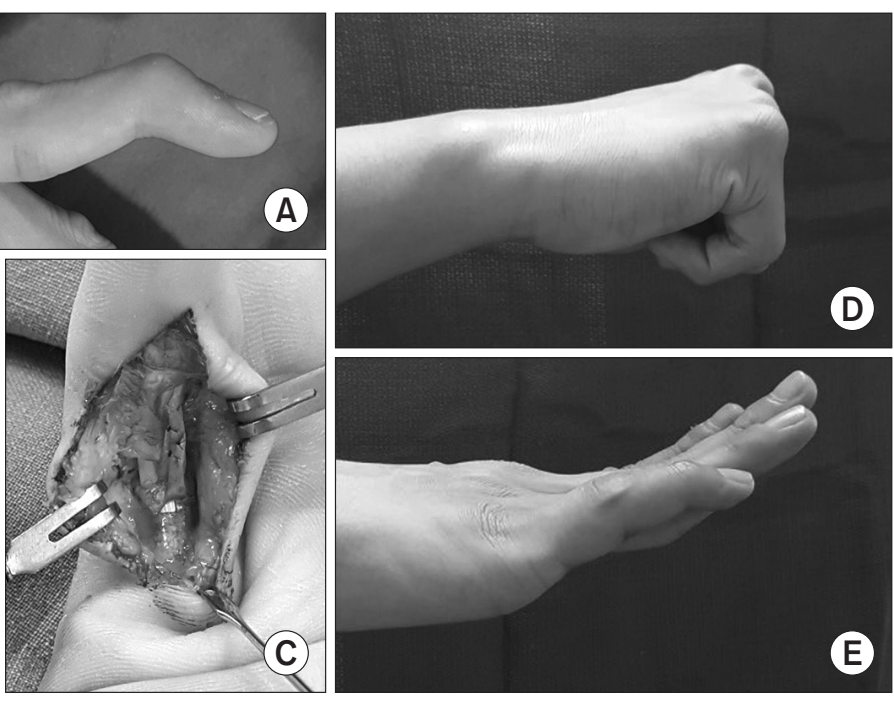

Figure 22. Flexor digitorum superficialis (FDS) tenodesis for a swan neck reconstruction. (A) Preoperative photo demonstrating post-traumatic swan neck deformities of the little finger. (B) One slip of the FDS is isolated, and the tendon is passed through the A2 pulley. (C) Completed FDS tenodesis with the tendon secured through the A2 pulley and sutured to itself. (D, E) Postoperative appearance demonstrating a mild flexion contracture and near full flexion of the proximal interphalangeal joint. 

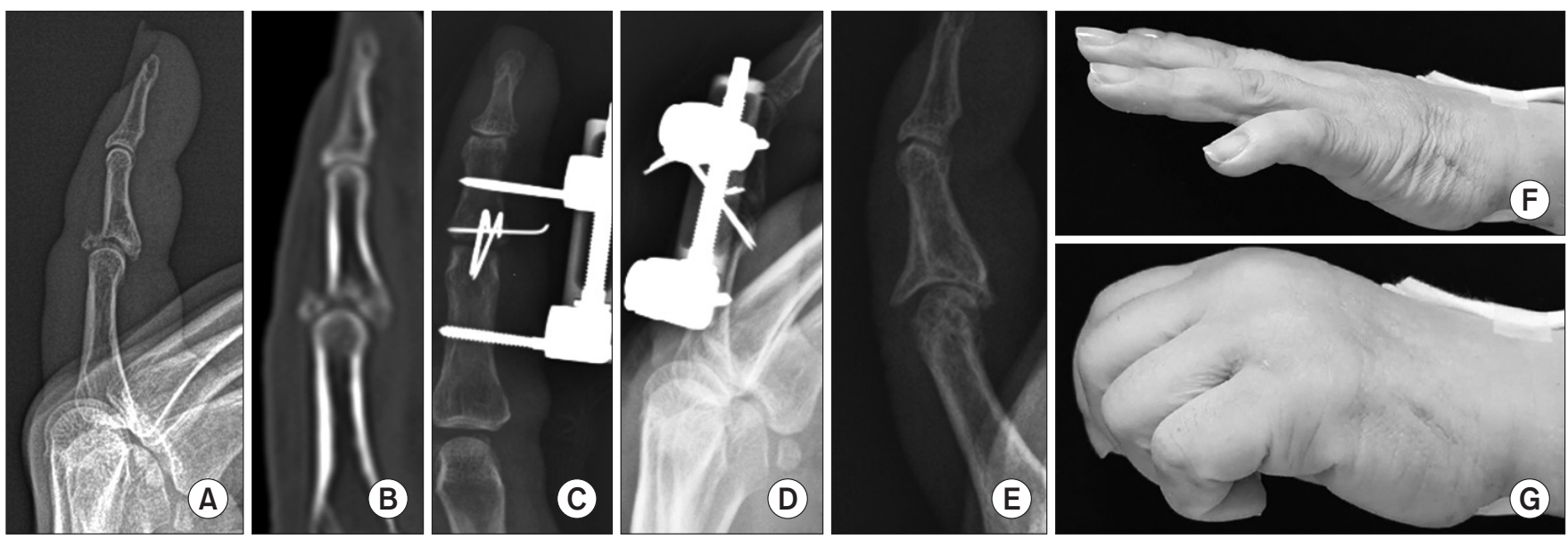

Figure 23. Articular remodeling after extension block pin and external fixation for severe comminution of the base of the middle phalanx. (A) Lateral radiograph and (B) computed tomography scan images of proximal interphalangeal joint fracture-dislocation with comminution and impaction of the little finger in a 65-year-old woman. (C) Anteroposterior and (D) lateral radiographs after extension block pinning and external fixation. (E) Lateral radiograph three years after surgery, showing consolidation of the fracture fragments and articular remodeling. (F, G) Follow-up shows excellent flexion with mild extension lag.
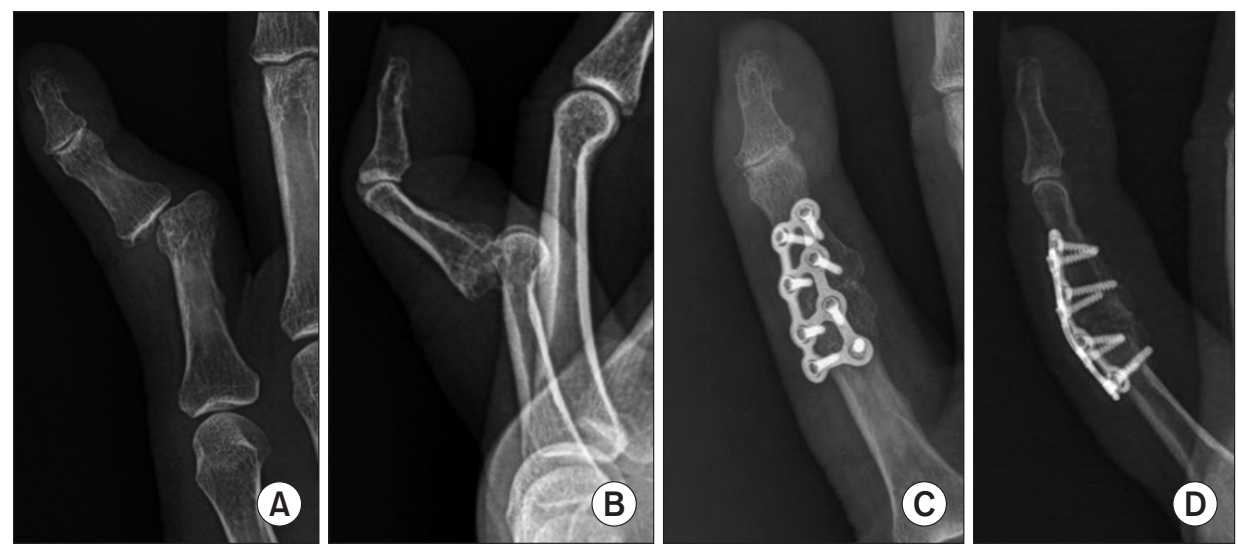

Figure 24. Proximal interphalangeal (PIP) joint fusion with locking plate. (A, B) A 50-year-old woman with chronic deformity and post-traumatic arthritis of the PIP joint of little finger after remote traumatic PIP joint injury. (C, D) Postoperative status of PIP fusion with a locking plate. Plate fixation allows rigid fixation at the desired angle.

지만 수지 골절 및 탈구는 복잡하고 다양한 연부조직의 동반 손 상으로 발생하여 적절한 치료 방침을 결정하기가 쉽지 않다. 새 로운 수술 기법과 삽입물의 발전으로 이전에 많은 합병증이 발생 했던 복잡한 형태의 골절 및 탈구의 치료에서도 좋은 결과들이 발표되고 있다. 따라서 수술 전 골절의 형태와 양상을 잘 이해하 고 각 환자의 상태에 맞는 적절한 접근법과 최소 절개, 안정적 고 정방법과 각성 수술접근 등을 이용하여 치료를 한다면 성공적인 결과를 얻을 수 있다.

\section{CONFLICTS OF INTEREST}

The authors have nothing to disclose.

\section{ORCID}

Ho Jung Kang, https://orcid.org/0000-0003-0273-1264

Ji Sup Kim, https://orcid.org/0000-0001-8448-1064

\section{REFERENCES}

1. Lutsky KF, Edelman D, Leinberry C, et al. A prospective evaluation of complications after use of exposed pins in the hand and wrist. Plast Reconstr Surg. 2019;144:659-64.

2. Bezuhly M, Sparkes GL, Higgins A, Neumeister MW, Lalonde DH. Immediate thumb extension following extensor indicis proprius-to-extensor pollicis longus tendon transfer using the wide-awake approach. Plast Reconstr Surg. 
3. Hyatt BT, Rhee PC. Wide-awake surgical management of hand fractures: technical pearls and advanced rehabilitation. Plast Reconstr Surg. 2019;143:800-10.

4. Hong J, Kang HJ, Whang JI, et al. Comparison of the wideawake approach and conventional approach in extensor indicis proprius-to-extensor pollicis longus tendon transfer for chronic extensor pollicis longus rupture. Plast Reconstr Surg. 2020;145:723-33.

5. Kang HJ, Lee SK. Open accurate reduction for irreducible mallet fractures through a new pulp traction technique with primary tendon repair. J Plast Surg Hand Surg. 2012;46:43843.

6. King HJ, Shin SJ, Kang ES. Complications of operative treatment for mallet fractures of the distal phalanx. J Hand Surg Br. 2001;26:28-31.

7. Leddy JP, Packer JW. Avulsion of the profundus tendon insertion in athletes. J Hand Surg Am. 1977;2:66-9.

8. Smith JH Jr. Avulsion of a profundus tendon with simultaneous intraarticular fracture of the distal phalanx: case report. J Hand Surg Am. 1981;6:600-1.

9. Al-Qattan MM. Type 5 avulsion of the insertion of the flexor digitorum profundus tendon. J Hand Surg Br. 2001;26:42731.

10. Kang N, Pratt A, Burr N. Miniplate fixation for avulsion injuries of the flexor digitorum profundus insertion. J Hand Surg Br. 2003;28:363-8.

11. Shewring DJ, Miller AC, Ghandour A. Condylar fractures of the proximal and middle phalanges. J Hand Surg Eur Vol. 2015;40:51-8.

12. McElfresh EC, Dobyns JH, O'Brien ET. Management of fracture-dislocation of the proximal interphalangeal joints by extension-block splinting. J Bone Joint Surg Am. 1972;54:170511.

13. Viegas SF. Extension block pinning for proximal interphalangeal joint fracture dislocations: preliminary report of a new technique. J Hand Surg Am. 1992;17:896-901.

14. Hynes MC, Giddins GE. Dynamic external fixation for pi- lon fractures of the interphalangeal joints. J Hand Surg Br. 2001;26:122-4.

15. Calfee RP, Kiefhaber TR, Sommerkamp TG, Stern PJ. Hemi-hamate arthroplasty provides functional reconstruction of acute and chronic proximal interphalangeal fracture-dislocations. J Hand Surg Am. 2009;34:1232-41.

16. Kuhn KM, Dao KD, Shin AY. Volar A1 pulley approach for fixation of avulsion fractures of the base of the proximal phalanx. J Hand Surg Am. 2001;26:762-71.

17. Yamanaka $K$, Yoshida $K$, Inoue $H$, Inoue A, Miyagi T. Locking of the metacarpophalangeal joint of the thumb. J Bone Joint Surg Am. 1985;67:782-7.

18. Buchler U, McCollam SM, Oppikofer C. Comminuted fractures of the basilar joint of the thumb: combined treatment by external fixation, limited internal fixation, and bone grafting. J Hand Surg Am. 1991;16:556-60.

19. Harness NG, Chen A, Jupiter JB. Extra-articular osteotomy for malunited unicondylar fractures of the proximal phalanx. J Hand Surg Am. 2005;30:566-72.

20. Teoh LC, Yong FC, Chong KC. Condylar advancement osteotomy for correcting condylar malunion of the finger. J Hand Surg Br. 2002;27:31-5.

21. Jupiter JB, Koniuch MP, Smith RJ. The management of delayed union and nonunion of the metacarpals and phalanges. J Hand Surg Am. 1985;10:457-66.

22. Wei DH, Terrono AL. Superficialis sling (flexor digitorum superficialis tenodesis) for swan neck reconstruction. J Hand Surg Am. 2015;40:2068-74.

23. Swanson A. Surgery of the hand in cerebral palsy and the swan-neck deformity. J Bone Joint Surg Am. 1960;42:951-64.

24. Curtis RM, Reid RL, Provost JM. A staged technique for the repair of the traumatic boutonniere deformity. J Hand Surg Am. 1983;8:167-71.

25. Stern PJ. Extensor tenotomy: a technique for correction of posttraumatic distal interphalangeal joint hyperextension deformity. J Hand Surg Am. 1989;14:546-9. 


\section{수지골절-탈구치료의최신지견 \\ 강호정 • 김지섭*凶}

연세대학교 의과대학 강남세브란스병원 정형외과학교실, *이화여자대학교 의과대학 이대서울병원 정형외과학교실

수지는 복잡한 구조와 필수적인 기능을 가진 신체 부위로, 외상에 노출되기 가장 쉬운 부위이다. 수지 골절의 치료 원칙은 적절한 고정으로 골절부의 안정성을 획득하는 것과 안정성을 담보로 한 조기 관절 운동 간의 균형을 신중하게 결정하는 것이다. 치료에도 불구하고 합병증으로 강직이나 변형 등으로 인해 기능적, 미용적 문제가 되는 경우가 많다. 본 종설은 수지 골절 치료의 최신 지견 을 소개하고, 치료가 어렵고 결과가 좋지 않은 것으로 알려진 관절면의 손상을 포함한 지절 관절 주위의 골절 및 탈구 위주로 정리 하였으며, 치료 증례 소개와 합병증에 대한 접근 및 치료 순서로 기술하였다.

색인단어: 수지, 골절, 탈구, 고정, 합병증

접수일 2020년 6월 23일 수정일 2020년 9월 1일 게재확정일 2020년 9월 7일 책임저자 김지섭

07804 , 서울시 강서구 공항대로 260, 이대서울병원 정형외과

TEL 02-6986-1774, FAX 02-2642-0349, E-mail kkimjsno1@naver.com, ORCID https://orcid.org/0000-0001-8448-1064 